\title{
Political Risk in Lithuania and Central Europe - Moderate Risk Analysis Model
}

\begin{abstract}
The political risk analysis investigates the influence that political decisions, or their absence, have on business. The author of the article describes the aims and methodology of the political risk analysis and claims that the methods employed by the leading companies engaged in political risk analysis are no longer sufficient for investigating political risk in the stable democracies. Risks like wars, massive commotion, or economic crises rarely occur in stable countries. However, new types of threats like the breach of technical standards, health risks, natural disasters, and anti-corporatism prevail. The author names them "the moderate political risks" and introduces the two-step moderate political risk analysis model. The model is verified by applying it to analyse the political risk in Lithuania and later comparing the risk in Lithuania with the risk in three other countries of the Central Eastern European region: Estonia, Poland, and Hungary. The analysis shows that the moderate political risk differs in the four countries, although the traditional political risk is very similar.
\end{abstract}

\section{Introduction}

The Central and Eastern European (CEE) region, which fully revealed itself to the world more than 16 years ago, (after the Cold war) is still charming and perspective, but unpredictable. The actual facts about the region are mixing with the myths and investment hopes are often overshadowed by disappointment. Despite the fact that one member of the G-8 club, 10 NATO members, and 8 member-states of the EU fit in the region, and also despite the astonishing GDP growth up to $8 \%$ per year, as well as exemplary democratisation, the region remains not fully known. The political risk experts are not fully acquainted with the regions, as well.

The same as the CEE region, the political analysis is also the result of dramatic changes of the $X X^{\text {th }}$ century. It became crucial to analyse and predict the impact political decisions can have on business after the new investment challenges had emerged, being that the geography and size of investment was extended and the interactivity of business and politics arose. Although the political risk analysis gradually turns from a management practice into a scientific

* Giedrius Surplys is a lecturer of the Lithuanian Military Academy. Address: Šilo 5a, LT-10322 Vilnius, Lithuania, tel. +370-610-49021; e-mail: giedrius@surplys.com 
doctrine, it is also facing challenges and is forced to renew its methodology constantly. One good example of a challenge is the CEE region, comprised of states that are of different stability and development. Hence, while analysing political risk within the $\mathrm{CEE}$, one of the actual methodological problems of the political risk analysis becomes clearly visible - the same assessment criteria no more applies to stable democratic countries on the one hand and to those living through war, raisings, or dictatorship on the other.

We will shortly present the concept of the political risk analysis and its methodology and then we will suggest the two-step moderate political risk analysis model, which should contribute to the research of risk in stable democracies. We will test the new model in the analysis of political risk in Lithuania. Then we will compare the result of this analysis to the findings of political risk research in Estonia, Poland, and Hungary.

\section{Political Risk - Practice and Science}

One of the main characteristics of globalisation is the birth of overlap and the interactivity of the fields of human activity. A common citizen can now strongly correct her/his governments' policies and is even more strongly influenced by them. Her/his business can no longer neglect ecology, religion, or principles of welfare, etc. An outcome of one of these overlaps - the increased interdependence between the economy and politics - is political risk or the influence or otherwise political decisions on business.

The political risk analysis, together with the economic and the financial risk analysis, form a contemporary discipline of risk management, which has the mission of ensuring safe business. According to Claude Erb, Campbell R. Harvey, and Tadas Viskanta, two factors decide the degree of risk in every country: the country's wish to pay, and ability to pay. Hence, the political risk decides the wish to pay, whilst economic and financial risks indicate the country's ability to pay. ${ }^{1}$

The expropriation of the property of foreign companies in Iran after the 1979 revolution, the attack of Russian authorities against Yukos in 2003, or the extremely friendly relationship between the Alijev dynasty in Azerbaijan and the British Petroleum, are all examples of political risk.

As the political risk analysis is a relatively young discipline (1980s can be treated as its beginning), ${ }^{2}$ the definition of its object has not been fully clarified yet and it is still fighting for its place within the system of political sciences. Different authors present different definitions of political risk. The directors of the Marwin Zonis and Associates, Marwin Zonis and Sam Wilkin, define political risk as "uncertainty that stems from the exercise of power by governmental

\footnotetext{
${ }^{1}$ Erb C. B., Harvey C. R., Viskanta T., "Political Risk, Economic Risk and Financial Risk", Financial Analysts Journal, November/December 1996, p. 29-31.

${ }^{2}$ Derringer H., Wang J., "Note on Political Risk Analysis", Harvard Business Review (Harvard Business School), September 17, 1997, p. 1-11.
} 
and non-governmental actors." ${ }^{3}$ Ian Bremmer, the political risk analyst of the Harvard Business Review and the president of the Eurasia Group claims that political risk is just the influence of politics on markets. ${ }^{4}$ The experts of the risk management giant, the Aon, consider political risk as the threats to business arising from governmental actions or incapability to act. ${ }^{5}$ Hence, normally, two factors characterise political risk:

- The exercise of political power or the incapability to exercise it;

- The influence of this exercise on business.

The aspect of business should be strongly stressed here because serving the needs of business, in particular, distinguishes the political risk analysis from the national security studies, the discipline it often confused with. As a matter of fact, the difference between the two disciplines is decided by the difference in their clientele. The goal of the national security studies is to assure security for all inhabitants of one country, whilst for the political risk analysis only the interests of national and foreign businesses are at stake.

The political risk analysis became a professional practice and has recently become an academic discipline because of the increase of business-scale in general and the beginning of active investment into unstable regions (because they have rich oil resources, cheap labour force, etc.). ${ }^{6}$ It is the aim of the political risk analysis to decide, which countries are secure enough to invest in and how to profit from political changes. ${ }^{7}$

According to Martin Stone, the director of the risk analysis department at the Control Risks Group, the task of the political risk analysis is to protect the personnel of business companies (from criminal activities or threats of ethnic or religious origin), the equipment (from attacks of politically motivated vandals or targeted terrorist attacks) and the assets (from expropriation or ban for money transfers to the country of origin). ${ }^{8}$ Taking into account the big role that the information society played by the image of the companies, we can also add protection of the image to the tasks of the political risk analysis (from labels like "corrupted company" or "anti-human-rights business").

Despite the fact that the political risk analysis has grown into entire scientific industry from ad hoc trips to the countries where the businesses had planned to invest or hasty investigation, anytime the need for investment had arisen (today it is taught at Universities, it has become a game of specialised

3 Zonis M., Wilkin S., "Driving defensively through a minefield of political risk", Financial Times Mastering Risk Series, 2000, p. 9-10.

4 Bremmer I., "Managing risk in an unstable world", Harvard Business Review, http://www.navigaterisk. com/risk/articles/ManagingRisk.cfm, 24-09-2006.

5 Aon, Enterprise risk management, http://www.aon.com/uk/en/risk_management/risk_consulting/erm. jsp, 18-08-2006.

6 Bremmer I., "Managing risk in an unstable world", Harvard Business Review, http://www.navigaterisk. com/risk/articles/ManagingRisk.cfm, 24-09-2006.

7 PWC Advisory and Eurasia Group, How managing political risk improves global risk performance, 2006, http://pwc.com/extweb/pwcpublications.nsf/docid/6c7fe77bcc684d01852571620083bd9a, 04-10-2006.

8 Stone M., "Scourges that strike at the heart of global business", Financial Times Mastering Risk Series, 2000, p. 12-13. 
political risk think tanks, and the companies like the British Petroleum have established separate political risk departments), incidents like September 11, massive riots in Hungary in 2006, or the Mohammad drawings scandal in January of 2006, are only a small number of those surprises that occur absolutely unexpectedly for political risk analysts. This makes constant revision of the methodology and the objects of the political risk analysis necessary.

I would like to contribute to this revision by introducing the two-step moderate political risk analysis model, using the case of the political risk in Lithuania. After having presented the model and having tested it on the Lithuanian case, I will verify it by comparing the political risk in Lithuania with the political risk in 3 other $\mathrm{CEE}$ countries.

\section{The Moderate Political Risk Analysis Model}

Ian Bremmer has written the article named "Managing risk in an unstable world" in 2006. ${ }^{9}$ It is logic that political risk is mostly linked to unstable countries, so the article names like that are very popular. However, more and more often the question of how to assess and manage political risk in the stable world becomes actual. The bombings in Madrid in autumn of 2003 and London in spring of 2005, as well as the wave of unstable governments in Lithuania, Poland, and Estonia in 2006 indicates that political threats are awaiting businesspeople in stable and democratic states.

\subsection{Methodological Problem}

The analysts meet a serious problem while investigating political risk in contemporary developed countries and constructing their risk ratings - they apply similar criteria to both developing, and even war experiencing states, also democratically stable countries. The usual factors of political risk (stability, capability of the government to preserve the unity of the territory and to ensure law and order, riots and raisings, threats of war and terrorism) are normally hardly identified in the Western European and the North American states that are living the époque of postmodernism. So these countries are marked as low-risk zones in the annual risk ratings and reports and no more of a detailed analysis is provided as there is a lack of indicators to evaluate the other risks. This causes problems because crises, like the riots in France or in Hungary in 2006, occur unpredictably. Also, the micro-level threats like diseases, NGO attacks, etc. are not foreseen.

\footnotetext{
${ }^{9}$ Bremmer I., "Managing risk in an unstable world", Harvard Business Review, http://www.navigaterisk. com/risk/articles/ManagingRisk.cfm, 24-09-2006.
} 


\subsubsection{Traditional Risk Indicators}

We will now analyse several of the most popular models of political risk analysis. Employing those models, the respectable political risk analysis companies provide comprehensive reports on political risk in merely every country of the world and form regional, as well as global risk ratings (Table 1). We will see that many of the variables used in these models cannot be applied to investigate risk in democraticly stable countries.

One of the traditional models of the quantitative political risk analysis, that has served as the fundamental for many specific practical methods, is the PSSI (political systems stability index), introduced by Dan Haendel, Gerald West, and Robert Meadow in 1974. ${ }^{10}$ It contains the indices of social-economic characteristics, governmental processes, and societal conflicts:

- Social-economic characteristics: ethno linguistic fractionalisation, GNP growth per capita, and energy consumption per capita;

- Governmental process: political competition, legislative effectiveness, constitutional changes per year, and irregular chief-executive changes.

- Societal conflict: riots, demonstrations, government crises, armed attacks, assassinations, coup d'etats, guerrilla warfare, and internal security forces per 1000.

\footnotetext{
${ }^{10}$ Derringer H., Wang J., "Note on Political Risk Analysis", Harvard Business Review (Harvard Business School), September 17, 1997, p. 1-11.
} 
Table 1 Traditional political risk indicators

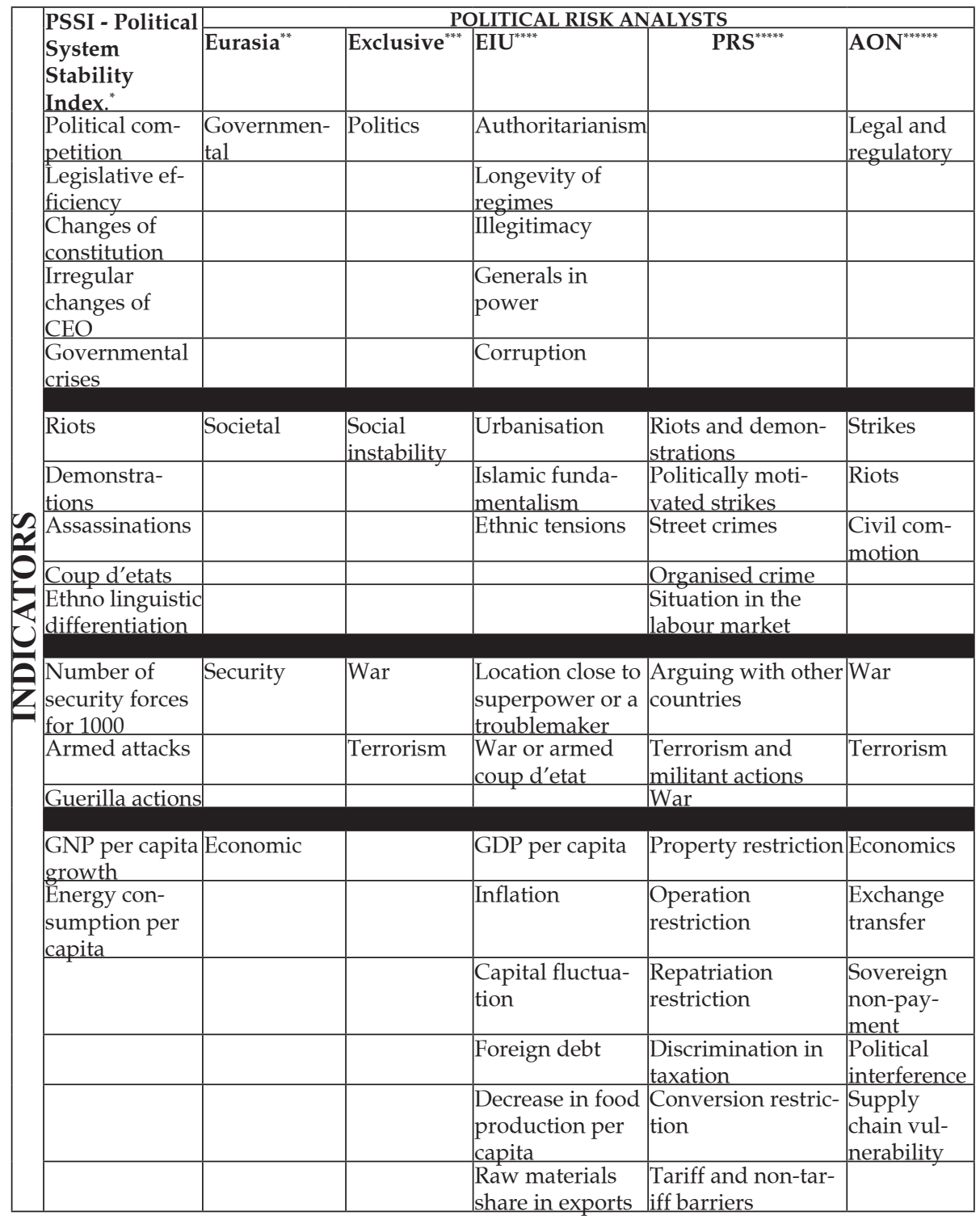

* Derringer H., Wang J., "Note on Political Risk Analysis", Harvard Business Review (Harvard Business School), September 17, 1997.

** Harvard Business Review, Eurasia Group methodology, 2006, http://www.navigaterisk.com/methodology/stabilityIndexExplained.cfm, 04-10-2006.

${ }_{* * * *}$ Exclusive Analysis, Lithuania country profile, http://exan.info/LT/, 04-10-2006.

***** Economist Intelligence Unit, Country Risk Service, 2006, http://graphics.eiu.com/files/ad_pdfs/ 2005CountryRiskService.pdf\#search='political\%20risk\%20ratings\%20free', 04-10-2006.

****** PRS Group, Country data, 2006, http://www.prsgroup.com/countrydata/countrydata.html, 04-10-2006.

****** Aon, 2006 Political and Economic Risk Map - Region Snapshots, 2006, http://www.aon.com/about/ publications/issues/political_risk_map.jsp. 
Using the PSSI and other theoretical models, the companies engaged in political risk analysis are: the Eurasia Group, Exclusive Analysis, Economist Intelligence Unit (EIU), Political Risk Services (PRS) and Aon. These companies have created their own research methodology. Although every political risk analyst employs its own methodology, basically their variables are the same. They can all be divided into four groups: governmental, societal, security, and economic threats. Furthermore, we will shortly overview the risk indicators of each of the above mentioned companies.

The Eurasia Group uses the specialised model of political risk in developing countries. The factors being investigated can be grouped into four categories: governmental, societal, security, and economic. ${ }^{11}$

The Exclusive Analysis employs four general indicator categories in order to estimate the political risk: war, terrorism, social instability and politics. To evaluate these indicators, the Exclusive Analysis uses qualitative analysis. ${ }^{12}$

The EIU analyses war, social instability, political violence, regime changes, institutional deficiency, corruption, and criminality as indicators of political risk. ${ }^{13}$

The PRS uses such factors as turmoil (riots and demonstrations, politically motivated strikes, disputes with other countries that may affect business, terrorism and guerrilla activities, civil or international war, street crime that might affect international business personnel, organized crime having an impact on political stability or foreign business), equity restrictions (limitations on the foreign ownership of businesses, emphasising sectors where limitations are especially liberal or especially restrictive), operations restrictions (restrictions on procurement, hiring foreign personnel, or locating business activities, as well as the efficiency and honesty of officials with whom business executives must deal and the effectiveness and integrity of the judicial system), taxation discrimination, repatriation restrictions, exchange controls, tariff barriers, and also other import barriers, etc. ${ }^{14}$

Finally, factors such as economics, exchange transfer, strikes, riots, civil commotion, war, terrorism, sovereign non-payment, political interference, legal and regulatory, and also supply chain vulnerability are decisive to the Aon's political risk analysis. ${ }^{15}$

\footnotetext{
${ }^{11}$ Harvard Business Review, Eurasia Group methodology, 2006, http://www.navigaterisk.com/methodology/stabilityIndexExplained.cfm, 04-10-2006.

${ }^{12}$ Exclusive Analysis, Lithuania country profile, http://exan.info/LT/, 04-10-2006.

${ }^{13}$ Economist Intelligence Unit, Country Risk Service, 2006, http://graphics.eiu.com/files/ad_pdfs/ 2005CountryRiskService.pdf\#search='political\%20risk\%20ratings\%20free', 04-10-2006.

${ }_{14}^{14}$ PRS Group, Country data, 2006, http://www.prsgroup.com/countrydata/countrydata.html, 04-10-2006.

${ }^{15}$ Aon, 2006 Political and Economic Risk Map - Region Snapshots, 2006, http://www.aon.com/about/publications/issues/political_risk_map.jsp.
} 


\subsubsection{The Case of Stable Countries}

It is obvious from the research of the variables of the five political risk analysis companies that many of the indicators of the social, security, and economic threats can not be applied to the democratic stable countries, e.g.: coup d'etats, riots, war, civil war, guerrilla warfare, deficit of food and energy, state debt, and sovereign non-payment, etc. Hence, the stable countries are often placed in the top positions of the political risk ratings; the risk is indicated as low in them and the gap between them and the developing countries rises to several tens of rating points. In the Aon's Political risk map of 2006 almost every member state of the EU is painted in the green colour of "low risk", whilst the major part of Africa, Asia and Latin America is marked as "medium-high" and "high" risk. ${ }^{16}$

However, that does not mean that political risk in the democratically stable states does not exist. There is a variety of threats in these countries, which are not identified by political risk analysts, or they fade in the light of severe risks, faced by the unstable regions. This is because only traditional risk indicators are used in global investigations.

\subsection{Two-Step Approach}

In order to analyse the political risk in stable states, it is necessary to introduce additional variables that would enable analysts to investigate moderate political risk. The moderate political risk does not cause massive commotion nor threats to the very functioning of businesses, but it demands extra costs and may cause moderate losses.

The new variables would help in creating the two-step model for political risk analysis. The first phase of the model is the research of traditional political risk. During the second stage, the political risk in highly stable countries would be additionally investigated by using additional indicators. We shall call the model the two-step moderate risk analysis model.

Employing the two-step approach, the analysts would be able to exercise a more sophisticated approach to research the political risk in stable democratic countries. As the outcome of the two-step model, every country that has been assessed as low traditional risk state would also have the moderate political risk evaluation (e.g. low traditional risk, and high moderate risk zone, etc.). Graphically the model is illustrated in Picture 1.

Factors like incapability of state apparatus to guarantee meeting technical standards (e.g. while constructing the buildings of public access or living houses), pandemics (e.g. SARS, Avian flu, etc.), natural disasters (e.g. annual floods in Central Europe, etc.), attacks by non-governmental organisations (NGOs) and press (e.g. Greenpeace campaigns against Lukoil because of con-

${ }^{16} \mathrm{Ibid}$. 
struction of the D6 oil-terminal in the Baltic sea) constitute moderate political risk. Some of the above mentioned risks are already included into the analyses of the respected political risk analysis companies. The Aon calls huge attention to pandemics in its political risk map for $2006^{17}$ and the EIU distinguishes infrastructure risk as separate risk category. ${ }^{18}$

One of the quickly emerging moderate political risks nowadays is the attacks of businesses carried out by NGOs (otherwise called anti-corporatism). Fighting for a cleaner environment or human rights, striving to combat starvation and diseases, entities like Amnesty International, Greenpeace, Oxfam, etc. can constantly lynch you in press, call for boycotts of your production, or even jump into your restaurant together with their tractor (as nationalist farmer José Bové did in one of the McDonald's restaurants in France, in 1999). NGOs are causing more and more headaches for a company's image, the equipment, and the personnel of business companies.

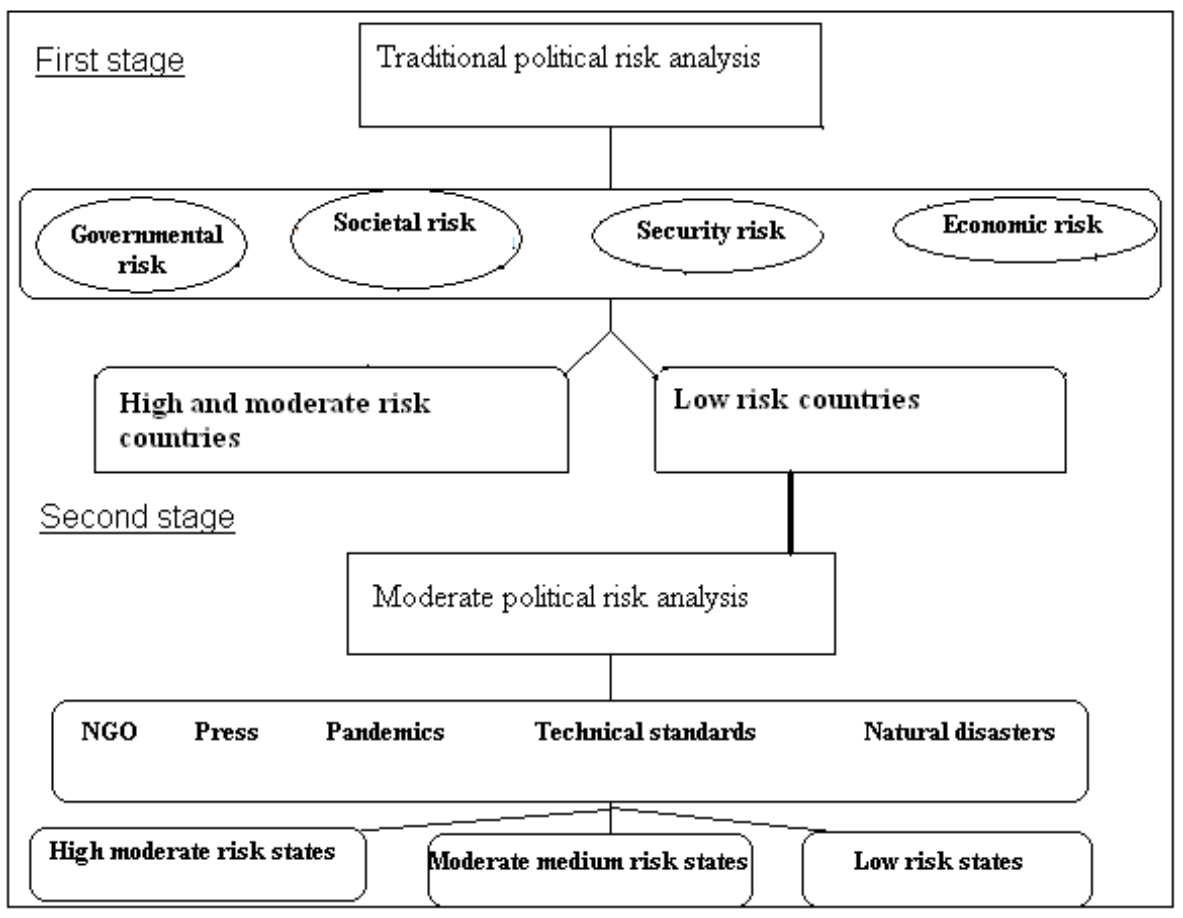

Picture 1. Moderate political risk analysis model

\footnotetext{
${ }^{17} \mathrm{Ibid}$

${ }^{18}$ Economist Intelligence Unit, Lithuania Risk: Risk Overview, 09-06-2006, http://www.eiu.com/index. asp?layout=VWPrintVW3\&article id=1690590354\&printer=printer, 24-09-2006.
} 
The media is also dangerous for the image in democratic countries. Objective and independent, or only pretending to be like that and serving somebody's interests as through some means of mass communication, can strongly damage your image.

In their political risk map for 2006, the Aon warns especially about the threat of pandemics, primarily - the Avian flu. ${ }^{19}$ And Jeffrey Staples adds to this warning that both political risk specialists and business are only learning to cope with risks like that. ${ }^{20}$ According to him, the pandemics differ from traditional risks in that they are only dangerous to human beings and are being hardly localised. In the case of traditional threats, the hazards are defined and then they are attempted to be neutralised or mitigated, and in the case of epidemics and pandemics, the threat lasts longer and it their trouble-spots can explode merely anywhere (for human beings and other virus-carriers travel from country to country). This is mainly because of global warming natural disasters (droughts and floods, frosts or earthquakes) are also becoming more and more tragic.

The reader might wonder whether threats like health risks or natural disasters can be considered as having any sort of political origin. Let us remember two factors, wen characterising the political risk (they were distinguished in the first chapter of the article): the exercise of political power or incapability to exercise it, and the impact of this exercise on business.

Of course the political authorities cannot prevent floods from happening (the fans of Jules Verne would never agree to this) neither can they create the pandemics (the authors of the conspiracy theories would object). However, the negative outcomes of the pandemics and natural disasters, or the activities of the NGOs, stem partially because the political authorities are not capable of taking sufficient prevention measures: they do not guarantee vaccination, do not regulate building of higher seawalls, do not watch-over meeting the requirements of ecological, anticorruption to other (thus creating the fields of reaction to NGOs), or approach too liberally the issue of the freedom of press, allowing the means of mass communication to become tools of economic influence, etc. hence, health risks, natural disasters, NGO and press attacks cause damage because the authorities cannot stop these threats (losses occur because of the incapability of the government to exercise power). Surely, the political risk specialists do not intend to be praising the abolishment of the freedom of expression and press, however the factual absence of anti-monopoly laws in the field of media (e.g. in Italy), insufficient responsibility for slander, disregard of ethical codes and other legal and administrative grey-zones that diminish the responsibility of NGOs and the press create conditions for the double two-face games with the smarty masks from the side of NGOs and the press.

An attempt to illustrate that damages of natural disasters or diseases

\footnotetext{
${ }^{19}$ Aon, 2006 Political and Economic Risk Map - Region Snapshots, 2006, http://www.aon.com/about/publications/issues/political_risk_map.jsp.

${ }^{20}$ Staples J., "Grist: A new type of threat", Harvard Business Review, 2006, http://www.navigaterisk.com/ risk/articles/TheOrganization.cfm, 26-09-2006.
} 
can be mitigated, this shows a clear example of the difference between countries of low moderate risk (Japanese government has managed by employing a range of means to minimise the damage of earthquakes) and high moderate risk countries (Hungary and Czech Republic cannot cope with the tremendous losses of annual floods).

It is easy to trace the influence of the above mentioned threats to businesses. Not meeting technical standards and health risks thereby create risks to people (personnel); natural disasters ruin the buildings (equipment) or cause the casualties (personnel); NGO attacks can threaten the equipment, personnel and primarily image. The attacks by the press are also targeted at the image of business companies. Hence, the pandemics, natural disasters, NGO and press attacks share both characteristics of political risk. Thus all these risks can be treated as political. We shall verify the two-step model of moderate political risk analysis on the case of Lithuania in the next chapter.

\section{Political Risk Analysis in Lithuania}

We shall first analyse the traditional risk in Lithuania, using the traditional methodology. We shall use both the data and evaluations of the above mentioned giants carrying out political risk analysis and the original evaluations and prognoses. After having assessed Lithuania as the country of low traditional risk, we shall proceed to analysing the moderate risk within the country. Then, in the following chapter we shall compare the results of the two-step Lithuanian political risk analysis to the political risk in other CEE countries.

In its political risk map for 2006, the Aon specifies Lithuania as the lowrisk zone..$^{21}$ The Exclusive Analysis also provides a similar evaluation. According to the experts of this company, the highest risk can be predicted in the category of political risks, because the country usually has instable governments and high corruption-rate (especially in the construction sector). ${ }^{22}$ The Exclusive Analysis also names intensive organised crime activities as another concern.

The EIU also places Lithuania in the group of countries with low-level risk. ${ }^{23}$ The analysts of the think-tank are convinced that almost no security threat exists in the country. Macroeconomic and taxation risks are also estimated low. Slightly higher risk is predicted in the categories of political stability (because of frequent changes of ministers), governmental effectiveness (corruption), legal and regulatory, labour market, financial system, and infrastructure.

\footnotetext{
${ }^{21}$ Aon, 2006 Political and Economic Risk Map - Region Snapshots, 2006, http://www.aon.com/about/publications/issues/political_risk_map.jsp.

${ }^{22}$ Exclusive Analysis, Lithuania country profile, http://exan.info/LT/, 04-10-2006.

${ }^{23}$ Economist Intelligence Unit, Lithuania Risk: Risk Overview, 09-06-2006, http://www.eiu.com/index. asp?layout=VWPrintVW3\&article_id=1690590354\&printer=printer, 24-09-2006.
} 


\subsection{Traditional Political Risk}

\subsubsection{Governmental (political) Risk}

The governmental, or otherwise - political risk, which is mostly criticised by both the Exclusive Analysis and the EIU, really is the most acute threat to business in Lithuania. The presidential scandal of Rolandas Paksas in 2003, the triumph of Viktor Uspaskich's political party in the parliamentary elections of 2004 and then quick fall, the corruption case of the mayor of Vilnius Artūras Zuokas in 2005 and other cataclysms make the Lithuanian political system hardly predictable and risky. This may threaten the stability of business contracts or even cause a chain-reaction of social commotion, similar to the one in Hungary in 2006.

The other threat, distorting the market and sometimes even breaking human rights, is corruption. Lithuania has ended in the relatively low $44^{\text {th }}$ position (out of 158 states) in the annual corruption rating of the Transparency International in 2005. As the data of the poll agency TNS Gallup indicates, inhabitants of Lithuania consider corruption to be the $3^{\text {rd }}$ biggest problem in the society (after low salaries and criminal activities). The heads of business companies, on the other hand, treat corruption as the $2^{\text {nd }}$ biggest problem after massive emigration. The inhabitants are convinced that the medical system, the police, parliament, courts, government, and municipal administrations are most corrupted. The heads of business companies name the same institutions to be most corrupted. ${ }^{24}$

The high rates of corruption in Lithuania means that businesspeople investing in the country are forced to pay bribes for the decisions the civil and other servants must take anyway. Thus the companies are risking loosing their profit and their employees are not guaranteed to receive proper medical service if they do not bend to the corruption pressure.

The governmental instability and political intrigues might turn into massive commotion soon. Both societal and economic processes might cause massive strikes. The high level of alcoholism in Lithuanian villages and the experience of strikes (the farmers periodically block roads, the strikes of teachers and medical staff have recently been organised) make the probability of massive commotion relatively high. The presidential scandal in 2003 has already shown that society can be very reactive on political questions (when the then president was travelling across the country, little clashes between his partisans and the opponents took place).

The upcoming joining of the euro zone will also have an additional thorn for dissatisfaction in the society. In the meantime, as the government is trying to restrain the level of inflation (obeying the requirement of the EU, under the Maastricht criteria), the interest rates are rising and additional taxes (e.g. the real estate tax for private owners) may be introduced. The price for heating

\footnotetext{
${ }^{24}$ Transparency International, Lietuvos korupcijos žemèlapis, 2005, http://www.transparency.lt/new/images/ tns gallup kz2005 prezentacija galutinis.ppt\#469,4,Visuomeniniu problemu svarbos vertinimas.
} 
rose by $20 \%$ in some municipalities in 2006 and the prices for fuel have fluctuated up to $20 \%$.

\subsubsection{Societal Risk}

High levels of criminal-intensity should be mentioned as the top societal risk. The Lithuanian criminal groups have bad fame for engaging in human and drug trafficking. The Council of Europe named Lithuania among the countries where human trafficking is highly intensive in its annual report in 2005. ${ }^{25}$ However, this type of criminal activity does not create a direct threat to business.

Much more dangerous to business companies are other sorts of criminal activities that are also popular in the country: robberies and car theft, as well as racketeering and blackmail. The Lithuanian criminal groups are especially advanced in the field of internet economic crimes. However, the level of some criminal activities is decreasing in Lithuania because of massive emigration to Western European countries. Such an example is the car theft - in 2006, the number of automobiles stolen went down by $25 \% .{ }^{26}$

The businesses would be in a much lower risk of becoming the victims of the criminal activities if they established their offices or venues of production or retail further from the so called "grey zones": villages or city districts where high level of alcoholism and criminality exist, cruel murders happen, and the murderers are never revealed and the police are not willing, nor capable of setting the order. An example of such a district is the Kirtimai district in Vilnius.

One more societal problem is the lack of physical labour force. After Lithuania joined the EU in 2004 and the labour markets of some EU countries opened to the Lithuanians, massive emigration erupted in the country. In the beginning of 2002, 3.476 million people lived in Lithuania and in the beginning of 2006 there were 73,000 people less. ${ }^{27}$ According to unofficial predictions, the actual number of emigrants might be as high as 400,000. Hence, the companies wishing to employ physical staff have to increase the salaries, organise transport for employees in areas of up to 100 kilometres (sic! - the length of Lithuanian territory is only $400 \mathrm{~km}$ in some places) and provide all sorts of other privileges. Despite this, businesses in the construction, production, wood industry and other sectors still cannot manage working with full power because they lack employees.

\footnotetext{
${ }^{25}$ O'Rourke B., "Europe: Council Of Europe Report Says Organized Crime Poses Threat To Democracy", Radio Free Europe/Radio Liberty, 26-01-2005, http://www.rferl.org/featuresarticle/2005/1/F7753263-8C4F4F41-9BFA-D3B2FF06CDFE.html. 01-09-2006.

${ }^{26}$ Lietuvos radijas, Lietuvoje sumažèjo automobiliu vagysčiu, 2006-02-21, http://www.delfi.lt/news/economy/ automoto/article.php?id=8833508, 23-08-2006.

${ }^{27}$ Lietuvos statistikos departamentas, Pagrindiniai rodikliai: gyventoju skaičius, 2006-02-21. http://www. std.lt/lt/pages/view/?id=1642\&PHPSESSID=cbf19f06aacdaf98a131a6542c15e65a, 14-04-2006.
} 


\subsubsection{Security Threats}

Despite the fact that both the Exclusive Analysis and the EIU estimate that the security risk as low in Lithuania, it cannot be completely neglected. Although Lithuania is in better relations with Russia than its Northern neighbours: Latvia and Estonia (Lithuania is the only Baltic state that has the border treaty with Russia ratified and there are no conflicts with Russia over the rights of Russian minorities in Lithuania), diplomatic rows, debates about the Kaliningrad transit or breaking of Lithuanian air space by the Russian flying objects occur rather often. In 2006, Russia stopped the oil flow to Lithuania after the oil refining factory Mažeikiu nafta (which had earlier belonged to the Russian Yukos) was sold by the Lithuanian government to the Polish oil company PKN Orlen. Although the diplomatic Moscow blamed the disruption of the oil supply on the necessary repair of the pipeline, many political specialists were sure that the real reason for stopping the oil flow was Moscow's disappointment that the Mažeikiu nafta was not sold to the Russian oil giant Lukoil.28

However, although the diplomatic relations with Russia are constantly on fire, the hazard from the other Eastern neighbour of Lithuania - Belarus cannot be overlooked. The countries cautiously demonstrate modestly friendly relations, but the regime of Alexander Lukashenko has expressed its fury several times over Lithuania's support to the Belarusian opposition. The regime, having a lengthy track of the breach of international law, may become unpredictable if it will feel the massive revolutionary urge arising in the society.

\subsubsection{Economic Threats}

Apart from the problems of the euro introduction and the boom of massive lending from the banks, the economic risks also arise from the big growth of GDP. In the beginning of 2006 the GDP growth in the country was even $8.8 \%{ }^{29}$ Such a big leap causes an increasing gap between the rich and the poor and might result in social tensions.

After having reviewed the political risk in Lithuania, we can conclude that it is a stable low-risk country, as there are no risks of coup d'etats or revolutions neither wars or economic depressions happen. However, despite the fact that the respected Western political risk analysis countries describe the country as the zone of low-risk, the risk report becomes more cautious when the analysis is carried out by a local analyst, who knows the spirit of the local society, the actual economic and criminal situation in different parts of the country and the possible scenario of political system. So, the real political risk situation in Lithuania may be a little worse than it appears in the reports of the Western companies.

\footnotetext{
${ }^{28}$ Iškauskas Č., "Energetinè sausra" su politiniu kvapeliu", Geopolitiniu tyrimu centras, 07-08-2006, http:// www.geopolitika.lt/index.php?lang=lt\&content=lt_geo 7 13\&parent=lt_geo_7, 08-08-2006.

${ }^{29}$ Lietuvos statistikos departamentas, BVP antrasis ivertis, 2006-08-29, http://www.std.lt/lt/news/view/ ?id=1502\&PHPSESSID=aefeef 9 ce 199115 cbcb1bf20105558d2, 01-09-2006.
} 


\subsection{Moderate Political Risk}

Just before presenting the moderate risk analysis of Lithuania and 3 more CEE countries, I must say my mea culpa to the academic society. This part of the article requires a much larger amount of paper, thus, as far as it was sandwiched into the strict frame, it is rather publicist. However, this leaves a lot of space for further thorough and detailed research.

In this chapter we shall analyse the risks of technical standards, health, natural disasters, and NGO or journalist anti-corporatism in Lithuania and shall compare the findings with the risks in Estonia, Poland and Hungary in the next chapter.

\subsubsection{Technical Standards}

Lithuania, as many other CEE states are experiencing the hardly controllable boom of the real estate prices. As the huge demand exists because of the mortgage services by the banks, this process causes a very hasty increase in supply, as the construction companies are being established and expand very fast. These companies build living houses and premises of other purpose in tremendous temps and the quality of the buildings is of very poor condition because of this rush. The construction companies overcome the technical standards and requirements by corruption or by finding "holes" in the legal system. ${ }^{30}$ The same way fire security, electric installation and security-at-work requirements are met. The incapacity of public authorities to ensure the meeting of technical standards results in the technical condition of the living, administrative, and production buildings being poorly satisfactory.

The road condition in Lithuania is good and much better than in the neighbouring countries: Latvia, Poland, Belarus, or the Kaliningrad Oblast of Russian Federation. With the financial assistance from the EU, new roads are being built and the old ones are being repaired. However, Lithuania has the worst situation in the EU in terms of traffic safety. ${ }^{31}$

\subsubsection{Health Risks}

The NGO Health Consumer Powerhouse acknowledged the public health service in Lithuania of the worst quality in Europe in 2006. ${ }^{32}$ Corruption among the medical personnel is a public secret in the country. Its indicators are highly raised by the pharmaceutical companies that use various gifts and financial

\footnotetext{
${ }^{30}$ Grižibauskienė E., "Griūčiu sezonas - ne už kalnų", Veidas, 08-06-2006, Nr. 23, http://www.veidas.lt/lt/ leidinys.full/448914803b81f?veidas=58a9ee0d993c7b1.

${ }^{31}$ European Union Road Federation, European Road Statistics 2006, http://www.erf.be/images/stat/ERF stats2006.pdf\#search='statistics $\% 20$ of $\% 20$ road $\% 20$ accidents $\% 20$ Poland $\% 2 \mathrm{C} \% 20$ Lithuania'.

${ }_{32}$ Lietuvos rytas, Lietuvos sveikatos sistema - prasčiausia Europoje, 27-06-2006, http://www.lrytas.

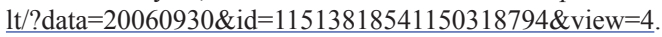


rewards in order to stimulate the doctors to prescribe their production to patients. Because of the actual system of medication and stationary treatment quotas, patients can buy necessary medication or stay in the hospital for stationary treatment only after bribing the doctors. This situation makes the Lithuanian public health very vulnerable and creates the threats of epidemics. In 2006, 30 towns and administrative units were announced the zones of the flu epidemic. ${ }^{33}$

So far no cases of pandemics were traced in Lithuania. But both in the cases of SARS and Avian flu explosions in the world Lithuania did not take any extra security measures. Hence, the state is not ready for tackling pandemics.

The bad medical service condition in Lithuania results in the business companies investing in the country must often take care of the health of their personnel themselves by applying to the private hospitals.

\subsubsection{Natural Disasters}

There are no highly harmful periodic natural disasters in Lithuania. ${ }^{34}$ Only the lagoon of river Nemunas close to the Courland bay (Klaipeda County) can be considered as the zone of risk as annual floods occur in spring. Certain danger for the health of personnel and the operation of personnel arises in cases of cold winters. In 2006 , the temperature used to fall below $-30^{\circ} \mathrm{C}$ in January).

\subsubsection{NGOs and Journalist Anti-Corporatism}

The echo of global fight between NGOs and businesses (anti-corporatism) can sometimes be heard in Lithuania. The Lithuanian Greens' Movement can be considered the most active anti-corporatist NGO in the country. The biggest victims of its actions are the Russian company Lukoil and the American fast food chain McDonald's. In 2003, the Lithuania Greens' Movement started the campaign aimed at stopping building of oil terminal D6 in the Baltic sea, close to the coast of the Courland Lagoon, by Lukoil. The purpose of the campaign was to call the society to boycott the production of Lukoil (it own one of the biggest petrol-station network in Lithuania). ${ }^{35}$ In 2002, the Greens started the range of campaigns against McDonald's restaurants in Lithuania. They were disseminating the leaflets describing the harm McDonald's causes to the health and the nature right at the doors of the restaurants. ${ }^{36}$

\footnotetext{
${ }^{33}$ LR Sveikatos apsaugos ministerija, Gripas iš Lietuvos pamažu traukiasi, 15-03-2006. http://www.sam. lt/sam/naujienos/?idi=3084, 11-05-2006.

${ }^{34}$ The CIA WorldBook, Field Listing - Natural Hazards, 30-11-2006, https://www.cia.gov/cia/publications/factbook/fields/2021.html, 01-12-2006.

${ }^{35}$ Lietuvos žaliujų judèjimas, Žaliuju kvietimas boikotuoti "LUKoil”" susilaukia vis didesnio pritarimo, 1407-2003, http://www.zalieji.lt/temos/Lukoil/Boikotas_vyksta, 03-10-2006.

${ }^{36}$ Lietuvos žaliuju judejimas, Lietuvos žaliuju judejiimas organizuoja akcija "McDonald's šiukšlina jūsu skrandị ir gamta," 01-02-2002, http://www.zalieji.1t/temos/McDonalds/McDonald_pranesimas, 03-102006.
} 
Human-rights (the Human rights observation institute), anti-corruption (the Transparency International Lithuanian bureau) and other sorts of NGOs are also spotting the faults of the business companies. One more influential $\mathrm{NGO}$ - the Roman Catholic Church - must not be neglected as well. It is highly recommended not to use religious symbols for commercial purposes in the country. In the end of 2005, the Public advertisement commission banned the use of Ripintojelis (the Lithuanian wooden statue of Jesus) in the Kalnapilis beer commercial. The ban was passed after one of the hierarchs of the Lithuanian Catholic Church, the archbishop Sigitas Tamkevičius had publicly denounced the commercial. A huge reaction from the Church had also arisen after the Polish company Sobieski placed a picture of the main places of pilgrimage in Lithuania (Aušros vartai - the Dawn gates) on the label of its new vodka.

The fact that the press enjoys many liberties in Lithuania (Lithuania is a relatively high $22^{\text {nd }}$ position in the Raporteurs sans frontieres index of press freedom for $2005^{37}$ ), also has negative aspects. The media easily overcomes the norms of the Public information law on slander and unlawful information collecting and become the tools of competition wars. The best example of employing media in politics and economy is the war between the two biggest dailies in Lithuania: Lietuvos rytas and Respublika that used to serve as the public stage for various interests, during the presidential impeachment in 2003. Both politicians and businesspeople were both participants and victims of the war.

The companies share a larger risk of becoming victims of media attacks because a relatively large share of the means of mass communication belongs to local capital (Lithuanian industry confederation owns a national television channel BTV, a national daily Lietuvos žinios and a national radio channel Radiocentras; the retail chain Senukai owns the national radio channel Žiniu radijas, etc.). Taking an active role in internal business and politics, the owners of the media can employ their means of mass communication for their own purposes without much restrain.

As we can see, the moderate political risks, which usually stem from the incapability of the government to ensure the obedience of legal norms causes big danger to business companies and requires additional costs. Threats of health risks, as well as of the anti-corporatist attacks require additional expenses in order to preserve the health of the personnel and the image of the company. And the overcoming of technical standards, without meeting them in Lithuania, may have tragic effects on the operation of the business.

\footnotetext{
${ }^{37}$ Raporteurs sans frontieres, Worldwide press freedom index, 2005, http://www.rsf.org/rubrique.php3?id_ru$\underline{\text { brique }=554}$.
} 


\section{Lithuania and the CEE Countries (Estonia, Poland and Hungary)}

We shall now verify the moderate political risk analysis model by comparing the evaluation of political risk in Lithuania with the evaluations of traditional political risk in the CEE countries, provided by the Exclusive Analysis and the Aon and the originally constructed assessment of the moderate political risk in these countries. Because of the limits of the article, we will only analyse three stable CEE democracies: Estonia (a little country), Poland (a big country), and Hungary (a medium-size country).

Two groups of states can be clearly distinguished in the CEE region (Table 2). In the $1^{\text {st }}$ group the political risk is still high and contains among other risks security threats (high probability of terrorism or armed conflicts and authoritarianism, etc.). The $2^{\text {nd }}$ group contains stable democratic members of the EU and NATO.

\section{Table 2. Political risk analysis in the CEE countries}

\begin{tabular}{|c|c|c|c|c|}
\hline & $\mathbf{A O N}^{*}$ & Exclusive Analysis ${ }^{\star *}$ & $\begin{array}{c}\text { Transparency } \\
\text { international }{ }^{* * *}\end{array}$ & $\begin{array}{c}\text { Raporteurs } \\
\text { Sans Fron- } \\
\text { tieres }^{\star \star \star \star \star}\end{array}$ \\
\hline Albania & High & & 126 & 62 \\
\hline Armenia & High & 2.5 (High) & 88 & 102 \\
\hline Azerbaijan & Medium-high & 2.5 (High) & 137 & 141 \\
\hline Belarus & Medium-high & & 107 & 152 \\
\hline $\begin{array}{l}\text { Bosnia and } \\
\text { Herzegovina }\end{array}$ & Medium-high & & 88 & 33 \\
\hline Bulgaria & Medium & 1.3 (Relatively low) & 55 & 48 \\
\hline Czech Rep. & Low & 0.6 (Low) & 47 & 9 \\
\hline Estonia & Low & 0.8 (Relatively low) & 27 & 11 \\
\hline Georgia & High & 3 (High) & 130 & 99 \\
\hline Montenegro & Medium-high & & 97 & 65 \\
\hline Croatia & Low-medium & & 70 & 56 \\
\hline Latvia & Low & 0.9 (Relatively low) & 51 & 17 \\
\hline Poland & Low-medium & 1.2 (Relatively low) & 70 & 55 \\
\hline Lithuania & Low & 0.9 (Relatively low) & 44 & 22 \\
\hline Macedonia & Medium-high & & 103 & 43 \\
\hline Moldova & high & 2.2 (Relatively high) & 88 & 74 \\
\hline Romania & Medium & 1.2 (Relatively low) & 85 & 70 \\
\hline Russia & Medium & 2.5 (High) & 126 & 138 \\
\hline Serbia & Medium-high & & 97 & 65 \\
\hline Slovakia & Low & 0.7 (Low) & 47 & 8 \\
\hline Slovenia & Low & 0.3 (Low) & 31 & 10 \\
\hline Ukraine & Medium-high & 1.9 (Relatively high) & 107 & 112 \\
\hline Hungary & Low & 0.7 (Low) & 40 & 12 \\
\hline
\end{tabular}

Remark 1. Grey fields mark medium-high and high risk countries.

Remark 2. Transparency International (corruption) and Raporteurs sans Frontieres (freedom of press) data indicate the country ranking ( 1 - the best result, last - the worst situation).

\footnotetext{
"Aon, 2006 Political and Economic Risk Map - Region Snapshots, 2006, http://www.aon.com/about/publications/issues/political_risk_map.jsp.

${ }^{* *}$ Exclusive Analysis, Lithuania country profile, http://exan.info/LT/, 04-10-2006.

${ }^{* * *}$ Transparency International, Lietuva, 2005, http://www.transparency.lt.

${ }^{* * * *}$ Raporteurs sans frontieres, Worldwide press freedom index, 2005, http://www.rsf.org/rubrique.php3?id_rubrique $=554$.
} 
Croatia can also be added to this group as a country of relatively low political risk. The Aon marks the country as the zone of medium-low risk. ${ }^{38}$ The countries in this group are described as low or relatively low risk countries. In order to analyse the political risk in these countries in detail it is necessary to employ criteria of moderate political risk.

\subsection{Comparative Analysis of Risk}

In order to illustrate how moderate political risk analysis reveals the differences among the low-level risk states, we shall compare the case of Lithuania with similar cases of Estonia, Poland and Hungary. We shall employ a typical method of risk assessment, taken from the business management theory, which counts the probability and expected harm of each threat (Table 3). ${ }^{39}$ Of course, the model is relative and is simplified to the case of the four countries investigated. Its aim is just to set guidelines for estimating the moderate political risk.

\section{Table 3. Moderate political risk in Estonia, Poland, Lithuania and Hungary}

\begin{tabular}{|c|c|c|c|c|c|}
\hline & $\begin{array}{l}\text { Technical } \\
\text { standards }\end{array}$ & Health risks & $\begin{array}{l}\text { Natural } \\
\text { disaster }\end{array}$ & NGO attacks & Media attacks \\
\hline Estonia & $\begin{array}{l}\text { Bad condition } \\
\text { of buildings; } \\
\text { Poor qual- } \\
\text { ity roads on } \\
\text { islands } \\
\end{array}$ & $\begin{array}{l}\text { AIDS epi- } \\
\text { demics }\end{array}$ & & $\begin{array}{l}\text { The greens, anti- } \\
\text { corruption and } \\
\text { human-rights } \\
\text { organisations }\end{array}$ & $\begin{array}{l}\text { The media is power- } \\
\text { ful, reactionary and } \\
\text { serves political and } \\
\text { economic interests }\end{array}$ \\
\hline Poland & $\begin{array}{l}\text { Bad condition } \\
\text { of buildings; } \\
\text { Poor quality } \\
\text { roads }\end{array}$ & & Floods & $\begin{array}{l}\text { The greens, anti- } \\
\text { corruption and } \\
\text { human-rights } \\
\text { organisations; } \\
\text { Catholic church } \\
\end{array}$ & $\begin{array}{l}\text { The media is power- } \\
\text { ful, reactionary and } \\
\text { serves political and } \\
\text { economic interests }\end{array}$ \\
\hline Lithuania & $\begin{array}{l}\text { Bad condition } \\
\text { of buildings; }\end{array}$ & $\begin{array}{l}\text { Bad medical } \\
\text { service con- } \\
\text { dition. Flu } \\
\text { epidemics in } \\
\text { winter }\end{array}$ & & $\begin{array}{l}\text { The greens, anti- } \\
\text { corruption and } \\
\text { human-rights } \\
\text { organisations; } \\
\text { Catholic church }\end{array}$ & $\begin{array}{l}\text { The media is power- } \\
\text { ful, reactionary and } \\
\text { serves political and } \\
\text { economic interests }\end{array}$ \\
\hline Hungary & $\begin{array}{l}\text { Bad condition } \\
\text { of buildings; }\end{array}$ & & Floods & $\begin{array}{l}\text { The greens, } \\
\text { anti-corruption } \\
\text { and human-rights } \\
\text { organisations }\end{array}$ & $\begin{array}{l}\text { The media is power- } \\
\text { ful, reactionary and } \\
\text { serves political and } \\
\text { economic interests }\end{array}$ \\
\hline
\end{tabular}

We shall estimate the probabilities of the risks of the technical standards, health, natural disasters, and anti-corporatism, measuring them as " 0 " if the threat has not revealed itself in practice and no probability can be foreseen for its occurrence (low risk or strong prevention), as " 0.5 " if the threat has not occurred but it is strongly expected to occur (strong risk and weak prevention)

\footnotetext{
${ }^{38}$ Aon, 2006 Political and Economic Risk Map - Region Snapshots, 2006, http://www.aon.com/about/publications/issues/political_risk map.jsp.

${ }^{39}$ Neverauskas B., Rastenis J. "Vadybos pagrindai”, Kaunas, Technologija, 2001.
} 
and " 0.9 " if the threat has already occurred and there is a tendency of periodic occurrence.

We will evaluate a little harm, in case of the occurrence of a threat as "1" (additional security measures have to be taken or the equipment, personnel, capital or image of the company is weakly harmed), a medium harm - as " 2 " (the equipment, personnel, capital or image of the company is harmed, but no hazard to the existence of the company arises), and a large harm - as " 3 " (the equipment, personnel, capital or image of the company are harmed to the extent which puts the very existence of the business into serious threat).

Naming risk probability as " $\mathrm{P}$ " and harm as " $\mathrm{H}$ ", we shall count the average level of risk " $R$ " in Lithuania, Estonia, Poland and Hungary under the formula:

$$
R=\frac{P_{n} \times H_{n}+P_{n+1} \times H_{n+1}+P_{n+2} \times H_{n+2}+P_{n+3} \times H_{n+3}}{n+3}
$$

The comparative analysis should indicate that these countries differ significantly in terms of the moderate political risk.

\subsection{Technical Standards}

As is the case of Lithuania, the countries of Estonia, Poland, and Hungary are also living through the construction fever. Because of the hasty constructions and using inadequate materials the risk of the spoilage or even the collapse of buildings is relatively high in all 4 countries (it is typical to all post-communist countries in Europe). ${ }^{40}$ For example, in the Estonian sea-resort of Parnu, which has only 45,000 constantly residing inhabitants, 1,000 new houses are built each year. ${ }^{41}$ In Poland the risk of collapse has turned into a catastrophe in January, 2006 when 66 people were killed when the roof of the exhibition centre collapsed in Katovice during the bird exhibition. The projectors of the exhibition centre were arrested with charges for unaccountable work after the tragedy. ${ }^{42}$ The roof under construction of the German pharmaceutical company Seissenschmidt AG also collapsed in Hungary, on the $11^{\text {th }}$ of November, 2006.

So, we can conclude that the risk probability in Lithuania and Estonia, which have not yet experienced the collapses, is medium, whilst it has already become high in Poland and Hungary. Surely, the harm of collapsing building

\footnotetext{
${ }^{40}$ Pankratov K. "It's a cold, wet and slippery world", British Helsinki Human Rights Group, 27-02-2006, http://www.bhhrg.org/mediaDetails.asp?ArticleID=935, 01-12-2006.

${ }^{41}$ Roman S., "Appartment building fever hits Parnu", Baltic Times, 06-04-2005, http://www.baltictimes. com/news/articles/12435, 24-02-2006.

${ }^{42}$ News from Poland, Arrests follow Katowice disaster, 22-02-2006, http://www.poland.pl/news/ article,Arrests follow Katowice disaster,id,212166.htm, 24-02-2006.
} 
must be measured as large. In that case, the risk of Lithuania and Estonia equals: $0.5 \times 3=1.5$ and that of Poland and Hungary $=0.9 \times 3=2.7$.

The group of 4 states splits into 2 blocks when speaking about the road quality. The businesspeople (especially working in the logistics) face narrow and often poor quality roads in Poland. Despite the fast reconstruction of roads, using the EU funds, the overall condition of roads remains poor. There are almost no highways in the country, thus trips and transportation in Poland last longer than in Lithuania, Hungary, and Estonia. The road infrastructure is poorly developed in the islands of Saaremaa and Hiuma, belonging to Estonia absolute majority of roads is still covered with gravel.

However, surprisingly the rate of road accidents where people are killed is highest in Lithuania (205 casualties per 1,000 inhabitants in 2003). The same rate in Poland is 149 casualties, in Hungary - 131, and 121 in Estonia. ${ }^{43}$ Hence, the businesspeople risk loosing the time and the money on the roads of Poland and loosing their lives on the roads of Lithuania.

While measuring the level of the road infrastructure risk, we shall assess bad road condition in the larger part of a country as high risk, bad road condition in a considerable part of a country as medium risk, and a good road condition as low risk. We shall estimate the harm of the bad road condition as low (requires additional investment). On the other hand we shall assess mortality on roads as medium harm (the personnel and equipment are seriously hurt, but that does not inflict on the very existence of the business) and give medium probability to it in Lithuania and low - in Poland, Estonia, and Hungary.

Based on such evaluations we shall come up to the following levels of risk-on-roads in the four countries:

- Lithuania. $R=[0.1 \times 1+0.5 \times 2] / 2=0.55$.

- Estonia. $R=[0.5 \times 1+0.1 \times 2] / 2=0.35$.

- Poland. $R=[0.9 \times 1+0.1 \times 2] / 2=0.55$.

- Hungary. $R=[0.1 \times 1+0.1 \times 2] / 2=0.15$.

Hence, the final level of the technical standards risk would be as follows:

- Lithuania. $R=[R 1+R 2] / 2=[1.5+0.55] / 2=1.025$.

- Estonia. $R=[R 1+R 2] / 2=[1.5+0.35] / 2=0.925$.

- Poland. $R=[R 1+R 2] / 2=[2.7+0.55] / 2=1.625$.

- Hungary. $R=[R 1+R 2] / 2=[2.7+0.15] / 2=1.425$.

43 European Union Road Federation, European Road Statistics 2006, http://www.erf.be/images/stat/ERF stats2006.pdf\#search='statistics $\% 20 \mathrm{of} \% 20$ road\%20accidents $\% 20$ Poland $\% 2 \mathrm{C} \% 20$ Lithuania' 


\subsection{Health Risks}

Because of the liberal politics of sexual services, Estonia runs strongly ahead of the 4 states in terms of the AIDS rate. According to the UNaids data, there were 7,700 people infected in Estonia in 2003, whilst in Lithuania the number was only 1,300, in Hungary - only 2,800, and in Poland - 14,000 (but compare - the population of Poland is close to 30 million and the 1 in Estonia is only 1 million). ${ }^{44}$

The statistic of the Health Consumer Powerhouse shows that the quality of the medical services is similarly poor in Estonia (20 th position in Europe), Poland (21), and Lithuania $\left(26^{\text {th }}\right) .{ }^{45}$ This means that the public health system is not ready to cope with epidemics or pandemics. The situation is better in Hungary - the $14^{\text {th }}$ position among European countries.

Generally, only the health protection system of Hungary is ready to properly combat health risks. However, a risk of a deadly disease (AIDS) exists only in Estonia (medium harm because death threatens solitary employees, but there is no risk to overall existence of business) - medium probability. A risk of diseases of smaller danger exists in other countries (small harm as it requires additional investment, but causes no serious outcomes). Hence:

- Lithuania. $R=0.5 \times 1=0.5$.

- Estonia. $R=0.5 \times 2=1$.

- Poland. $R=0.5 \times 1=0.5$.

- Hungary. $R=0.1 \times 1=0.1$.

\subsection{Natural Disasters}

Massive floods occur in Poland (the river Wystula basin) ${ }^{46}$ and Hungary (the river Danube basin) ${ }^{47}$ every spring because of the global warming. An estimated 35,000 people were evacuated from 200 villages during the flood of 2001 in Hungary. In Circa 90\% of live-stock died and 2,100 houses were ruined during the flood. ${ }^{48}$ Small floods also occur during the spring in Estonia. ${ }^{49}$

As floods in Poland and Hungary occur annually and the governments are incapable of mitigating their negative impact, we shall assess the probabil-

\footnotetext{
${ }^{44}$ Lietuvos AIDS centras, Table of country specific HIV/AIDS estimates and data, end 2003. 2004 Report on global AIDS epidemic, http://www.aids.lt/download.php.

${ }^{45}$ Health Consumer Powerhouse, Euro Health Consumer Index 2006, 2006, http://www.healthpowerhouse. com/media/EHCI2006.pdf.

${ }^{46} \mathrm{CIA}$ World Fact Book, Poland country profile, http://www.cia.gov/cia/publications/factbook/geos/pl.html, 23-03-2006.

${ }^{47}$ Hanko Z. G., "Flood Risks in Hungary", World Bank Group: Rural Development, http://wbln0018.worldbank.org/ECA/ECSSD.nsf/21fa768764fd12de85256bf1005aac54/663b3e89ad8f7f3985256cae0076e51a, 04-10-2006.

${ }^{48}$ Ibid.

${ }^{49}$ CIA World Fact Book, Field listing - Natural hazards, 11-30-2006, https://www.cia.gov/cia/publications/ factbook/fields/2021.html, 12-01-2006.
} 
ity of the risk in those countries as high. The harm is also high in Poland and Hungary. On the other hand, the probability of significant floods in Lithuania and Estonia is low and the harm is little:

- Lithuania. $R=0.1 \times 1=0.1$.

- Estonia. $R=0.1 \times 1=0.1$.

- Poland. $R=0.9 \times 3=2.7$.

- Hungary. $R=0.9 \times 3=2.7$.

\subsection{NGOs and Journalistic Anti-Corporatism}

In Poland, the green-movement NGOs are very active (the Ecology club of Poland, Freedom and Peace, Anarchist organisation, Movement for alternative society, etc.). There were approximately 100 green organisations in Poland in $1996 .{ }^{50}$ The greens actively participate in environmental protection campaigns. In one of those, the activists of the Greenpeace stopped the disembarkation of genetically modified food products at Gdynia port in November 2005. ${ }^{51}$ The activities of the greens are also visible in Estonia and Hungary. As in Lithuania, all other sorts of NGOs also threaten businesses in the 3 countries.

According to the $B B C$ analysts, the majority of the Hungary's leading national daily papers is pro leftist-liberal (Nepszabadsag, Magyar Hirlap, Nepszava) and are in good relations with political parties sharing the same ideology (), and with their financial supporters, obviously. The conservative trend is followed by the Magyar Nemzet. In 1998-2002, the centre-rightist parties who were in power were trying to break this balance by financing indirectly the right-wing Magyar Nemzet. But when the leftists and liberals returned to power, they stopped this indirect financing. ${ }^{52}$

The different situation from those in Lithuania and in Hungary is in Poland, where foreign capital is strongly established in the media market. This helps avoiding too much subjectivity and the biased participation of press in politics and business. The leftist trend is followed by the Trybuna and the Gazeta Wyborcza, whilst the rightist position is strongly protected by the media concern of the nationalist catholic priest Tadeusz Rydzik with its biggest flagmen: Radio Maryja and Nasz Dziennik. ${ }^{53}$

Foreign investment is also significant in the Estonian media market (especially from the Scandinavian countries and Norway). ${ }^{54}$ The country is

\footnotetext{
${ }^{50}$ Duijvelaar C., "East-East cooperation among environmental NGOs in Central and Eastern Europe", Regional Environmental Center, May 1996, http://www.rec.org/REC/Publications/BeyondBorders/ch34. html, 03-10-2006.

${ }^{51}$ Greenpeace, Greepeace confronts GE-ship on Polish waters, 17-11-2005, http://www.greenpeace.org/international/press/releases/greenpeace-confronts-ge-ship-o, 27-09-2006.

${ }^{52}$ BBC Monitoring: European press profiles, The press in Hungary, 2006, http://news.bbc.co.uk/2/hi/europe $/ 4068565 . \mathrm{stm}$.

${ }^{53}$ BBC Monitoring: European press profiles, The press in Poland, 2006, http://news.bbc.co.uk/2/hi/europe $/ 4470102 . \mathrm{stm}$

${ }^{54}$ BBC, Country profile: Estonia, 2006, http://news.bbc.co.uk/2/hi/europe/country_profiles/1106425. $\underline{\text { stm\#media. }}$
} 
scored high in the Media freedom rating - the $11^{\text {th }}$ position in the world. ${ }^{55}$ This diminishes the responsibility of the press, supported by the fact that the Estonian journalists' union has not yet passed the Code of journalistic ethics. ${ }^{56}$

The risk of anti-corporatism in the CEE states is only acquiring speed, as both the means of mass communication and the NGOs are currently only learning to make the difference.

Assessing the moderate political risk in the CEE countries in general, it must be stated that the annual floods in Poland and Hungary can have dramatic impact on business. Just because of this risk the two can be marked as high moderate risk countries. The moderate political risk in Poland can be assessed higher than in Hungary, however, because of the worse quality of roads and medical services.

Estonia and Lithuania can be indicated as medium, moderate risk countries. The biggest risk to business (personnel in particular) emerges from the high AIDS level in Estonia. The probability of this risk increases because of the liberal sex industry policies and high drug abuse rates (possibility of being infected against your own will) in the country. But the overall expectation to be infected is relatively low. The other risk in Estonia is the bad road conditions on their islands.

Lithuania can be assessed as the country with the low-medium level of moderate political risk. The risk level here is lower than in the other three countries investigated. Although the spectrum of moderate risks is rather wide, the risks that might have critical impact on business do not exist. The most acute threats in the country are related to poor regulation in terms of technical standards and bad medical service quality. However, the probability of serious hazards in these fields is really small. The most expected threats arise from the NGOs and the press. These threats can seriously damage the image of business companies.

\section{Conclusions}

The analysis of the traditional political risk is currently facing the problem when traditional risk indicators like war, sores of the authoritarian regime, raisings, riots, and economic crises cannot be applied anymore in stable democratic countries. This results in stable countries being marked as low-risk zones in the global risk ratings or reports and the more detailed analysis of risks in those countries not being provided. But the majority of the stable democratic states face new political threats nowadays, like anti-corporatism, breach of technical standards, natural disasters and health risks. These risks are named moderate political risks in the article. They can be analysed by employing the newly

\footnotetext{
${ }^{55}$ Raporteurs sans frontieres, Worldwide press freedom index, 2005, http://www.rsf.org/rubrique.php3?id rubrique $=554$.

${ }^{56}$ Loit U. "Estonia: self-regulation rather than state-regulation", European Journalism Centre, Organising media accountability: Experiences in Europe, 2005, http://www.ejc.nl/hp/mas/loit.html. 02-10-2006.
} 
introduced two-step moderate political risk analysis model. The model can be used in investigating political risk in stable democratic countries.

We thoroughly analysed the political risk in Lithuania to verify the twostep model. The analysis has shown that despite the fact that the level of traditional risk is minimal in the country, and the respectable companies engaging in the political risk analysis describe Lithuania as the low-risk country, business can face significant moderate risks in the country. Not meeting technical standards (the risk to the personnel and equipment), health risks (threat to the personnel), and anti-corporatism (threat to the image of business companies) are singled out as the main moderate risks.

The comparative analysis of the Lithuanian political risk and the political risks in the other three states of the CEE region: Estonia, Poland, and Hungary has shown that the countries where the traditional political risk is low differ significantly in terms of the moderate political risk level. Lithuania and Estonia were prescribed to the group of the medium moderate risk, and both Poland and Hungary were evaluated as high moderate risk zones. 